\title{
Wybrane zakażenia bakteryjne - nieuniknione zagrożenia zdrowia i życia człowieka
}

\section{Selected bacterial infections - unavoidable threats to the health and lives of the man}

\author{
Izabela Anna Sobieraj-Garbiak, Marta Drożdżyńska \\ Zespół Pracowni Medycyny Laboratoryjnej 109. Szpitala Wojskowego z Przychodnią \\ Samodzielny Publiczny Zakład Opieki Zdrowotnej \\ ul. Piotra Skargi 9-11, 70-965 Szczecin \\ Kierownik: ppłk dr n. med. Małgorzata Jekel-Juźwiak \\ Zakład Analityki Medycznej Katedry Diagnostyki Laboratoryjnej i Medycyny Molekularnej \\ Pomorskiego Uniwersytetu Medycznego w Szczecinie \\ al. Powstańców Wlkp. 72, 70-111 Szczecin \\ Kierownik: prof. dr hab. n. med. Maria Jastrzębska
}

\begin{abstract}
SUMMARY
In the present study we wanted to show that bacterial infections are an important factor threatening both the health and life of humans. This problem concerns the global population, both in developed and developing countries, and is often the cause of a significant proportion of deaths due to the negative impact of exo- and endotoxins on the host. Numerous infectious diseases caused by biological factors are undoubtedly associated with various risk factors. Despite the continuous development of medicine and countless actions spreading knowledge about bacterial gastrointestinal infections and
\end{abstract}

sepsis, these conditions are still not marginal in the everyday hospital environment.

Particular attention in this work was put on hospital infections because they are a major public health concern. Although a significant increase in awareness of the problem has been observed in Poland in recent years, this is still an important problem for medicine, and is also an economic issue. In addition, bacteria and their toxins can be used as a biological weapon for terrorist attacks.

Key words: infectious diseases, nosocomial infection, poisoning the digestive tract, septic shock, bioterrorism.

\section{STRESZCZENIE}

W niniejszej pracy wykazano, że zakażenia bakteryjne są istotnym czynnikiem zagrażającym zdrowiu i życiu człowieka. Zakażenia te dotykają ludności całego świata, zarówno w krajach rozwiniętych, jak i rozwijających się. Często są przyczyną znacznego odsetka zgonów ze względu na negatywny wpływ egzo- i endotoksyn na organizm gospodarza. Licznie występujące choroby zakaźne powodowane przez czynniki biologiczne są bez wątpienia związane z różnorodnymi czynnikami ryzyka.

Pomimo ciągłego rozwoju medycyny i niezliczonych akcji szerzacych wiedzę na temat bakteryjnych zakażeń przewodu pokarmowego i sepsy, schorzenia te wciąż nie są marginalnymi zdarzeniami w szpitalnej codzienności. Szczególną uwagę w pracy poświęcono zakażeniom szpitalnym ze względu na to, że są głównym problemem zdrowia publicznego. Chociaż w Polsce obserwuje się w ostatnich latach znaczny wzrost świadomości tego problemu, nadal stanowią one ważny problem medyczny i ekonomiczny. Oprócz tego należy mieć na uwadze, że bakterie i ich toksyny mogą zostać użyte jako broń biologiczna w atakach terrorystycznych.

Słowa kluczowe: choroby zakaźne, zakażenia szpitalne, zakażenia przewodu pokarmowego, sepsa, bioterroryzm.

\section{WSTĘP}

Bakterie są grupą mikroorganizmów o budowie jednokomórkowej, które potrafią przeżyć we wszystkich środowiskach zarówno na głębokości 3 tys. m pod ziemią, jak i na wysokości 32 tys. m ponad nią. Wytrzymują temperaturę wrzenia wody oraz ciśnienie kilkuset atmosfer. Ze względu na kosmopolityzm bakterii chorobotwórczych nie można zapobiec stałemu ich kontaktowi z człowiekiem.

Nazwę „bakterie” wprowadził w 1838 r. Christian Gottfried Ehrenberg, jednakże mimo iż o istnieniu bakterii chorobotwórczych wiedziano już w XIX w., nie znano skutecznej chemioterapeutyki do walki z wywoływanymi przez nie schorzeniami.
Zwolennikiem teorii wywoływania chorób przez bakterie był Robert Koch. Pracując nad prątkami gruźlicy, potwierdził swoją teorię dotyczącą rozwoju chorób bakteryjnych.

Pierwszy lek umożliwiający skuteczne zwalczanie bakterii wywołujących kiłę, Salwarsan, opracowany został przez Paula Ehrlicha i Sahachiro Hatę, a do użycia wszedł w 1910 r. Stworzona przez Hansa Christiana Grama metoda barwienia preparatów bakteriologicznych, od jego nazwiska zwana metodą Grama, pozwala na klasyfikację bakterii na Gram-ujemne i dodatnie ze względu na różnice w budowie ściany komórkowej. Jest to widoczne w preparatach barwionych tą metodą bakterie Gram-ujemne barwią się na kolor różowo-czerwony, a Gram-dodatnie na kolor niebiesko-fioletowy [1]. 
TABELA 1. Schorzenia wywoływane przez bakterie Gram-dodatnie i Gram-ujemne

\section{Zakażenia wywołane przez bakterie Gram-dodatnie}

gronkowcowe, paciorkowcowe, pneumokokowe, błonica, listerioza, różyca, wąglik, zatrucie jadem kiełbasianym, tężec, zgorzel gazowa

\section{Zakażenia wywołane przez bakterie Gram-ujemne}

Proteus species, meningokokowe, pałeczką okrężnicy, pałeczką ropy błękitnej, dur brzuszny, dury rzekome, inne salmonellozy, czerwonka bakteryjna, zakażenia wywołane przez Haemophilus influenzae, Klebsiella, Enterobacter, Serratia, Hafnia, krztusiec, legionelozy, pastereloza, tularemia, bruceloza, choroba kociego pazura, nosacizna, jersiniozy, dżuma, cholera
W 1928 r. Aleksander Fleming odkrył penicylinę wykazującą silne działanie bakteriobójcze, co rozpoczęło nowy etap w terapii zakażeń bakteryjnych. Wprowadzenie do lecznictwa penicyliny G zapoczątkowało rozwój antybiotykoterapii [2], metody skutecznej w eliminowaniu przyczyn zakażeń bakteryjnych zagrażających zdrowiu i życiu, a prowadzącej do pełnego wyleczenia organizmu. Jednakże nierozważna polityka antybiotykowa i zdolność bakterii do wytwarzania mechanizmów obronnych, zawierających geny oporności na antybiotyki, doprowadziła do wytworzenia przez bakterie różnych mechanizmów antybiotykooporności, która powoli staje się zmorą naszych czasów.

\section{DEFINICJA CHORÓB ZAKAŹNYCH I CZYNNIKI JE WYWOŁUJĄCE}

Choroby zakaźne to choroby wywołane przez czynnik biologiczny (bakterie, wirusy, grzyby, pierwotniaki) oraz biologicznie czynne substancje wy twarzane przez ten czynnik - toksyny bakteryjne (egzo- i endotoksyny). Przez długie stulecia choroby te były jednym z głównych problemów zdrowia publicznego. Uczeni Pinel, Farr, Joseph Ignace Guillotin, Louis-René Villermé zastanawiali się nad związkiem umieralności z warunkami życia i pracy. Badający warunki życia i stan zdrowia robotników z Górnego Śląska Rudolf Virhoff twierdził, iż do wywołania gruźlicy oprócz czynnika zakaźnego przyczyniają się warunki pracy i życia.

Za wystąpienie choroby odpowiedzialne są trzy elementy: czynniki gospodarza, swoiste czynniki chorobotwórcze oraz środowisko oddziałujące na człowieka. Choroby te dzielą się na choroby zakaźne rozwijające się u osobników niezwiązanych ze środowiskiem szpitalnym, np. pacjenci leczeni ambulatoryjnie (zakażenia pozaszpitalne), oraz choroby zakaźne rozwijające się u pacjenta hospitalizowanego (zakażenia szpitalne) [3, 4, 5, 6].

Schorzenia można podzielić ze względu na rodzaj bakterii, które je wywołują (tab. 1) [4].

\section{CHOROBY ZAKAŹNE - CZYNNIKI RYZYKA, ZAPOBIEGANIE, MECHANIZMY OBRONNE CZŁOWIEKA}

Polska jest jednym z krajów, w którym choroby zakaźne są nadal poważnym problemem zdrowotnym, mimo spadku zapadalności na większość z nich. Pod względem zachorowalności na groźne choroby zakaźne, zatrucia i zakażenia pokarmowe oraz gruźlicę, Polska ciągle plasuje się na wysokim miejscu w porównaniu z krajami Europy Zachodniej [7].

W przypadku gruźlicy Polska w 2011 r. zajmowała 7. miejsce pod względem liczby zachorowań ze współczynnikiem 22,2 (na 100 tys. mieszkańców), po Rumunii $(89,7)$, Litwie $(58,7)$, Łotwie (39,7), Bułgarii $(32,1)$, Estonii $(25,4)$ oraz Portugalii $(23,9)$, podczas gdy średnia zapadalność w Unii Europejskiej z Norwegią i Islandią wynosiła 14,2 [8].

W przypadku zakażeń i zatruć pokarmowych w $2011 \mathrm{r}$. obserwowano w Polsce spadek zakażeń bakteryjnych oraz znaczący wzrost zakażeń wirusowych. Zarejestrowano 490 ognisk zakażeń/zatruć pokarmowych powodowanych przez wirusy (36,5\% ognisk i 40,6\% zachorowań) oraz odzwierzęce typy pałeczek Salmonella (35,5\% ognisk i 27,8\% zachorowań). W 22,2\% ognisk nie udało się ustalić czynnika sprawczego. Najczęstszymi miejscami wystąpienia ognisk były mieszkania prywatne i szpitale. W przypadku ognisk o nieustalonym czynniku etiologicznym obserwowana była sezonowość podobna jak w ogniskach o etiologii wirusowej, co sugeruje zwrócenie uwagi na wykonywanie badań diagnostycznych w kierunku czynników wirusologicznych [9].

Na zdrowie populacji wpływa wiele mechanizmów o znacznej różnorodności i zmienności w czasie. Do zwiększonej wrażliwości na wystąpienie choroby zakaźnej przyczyniają się czynniki ryzyka, którymi są działania wiążące się z ryzykownym stylem życia, niekorzystnymi czynnikami biologicznymi, zagrożeniami środowiskowymi i społeczno-ekonomicznymi.

Czynników ryzyka przyczyniających się do utrzymywania się klasycznych form zakażeń i pojawiania się nowych postaci chorób zakaźnych jest bardzo dużo. Do najczęstszych zalicza się: nieprzestrzeganie procedur higieny osobistej i higieny żywienia, zmianę sposobu życia i zwyczajów żywieniowych w miejscach żywienia zbiorowego, niedostateczną świadomość zdrowotną, stosowanie środków odurzających, wykonywanie tatuaży, ryzykowne zachowania seksualne, zwiększoną podatność na zakażenia związane z występowaniem katastrof ekologicznych, trzęsień ziemi, powodzi, wojen i przymusowej migracji ludności, masowe przemieszczanie się ludzi zagrażające zawleczeniem chorób zakaźnych, skażenie biologiczne środowiska, zmiany struktury demograficznej społeczeństw związane z przedłużaniem czasu przeżycia osób zdrowych i chorych, zwiększającą się liczbę osób będących potencjalnym źródłem zakażenia, stosowanie preparatów przeciwbakteryjnych przyczyniające się do wzrostu liczby szczepów opornych na działanie leków, ciągły wzrost inwazyjnych medycznych metod terapeutycznych, niestabilność społeczną, ekonomiczną i polityczną powodująca zwiększania 
obszarów ubóstwa i niedożywienia. Dodatkowe zagrożenie stwarzają dzikie zwierzęta, szczególnie ptaki, mogące przenosić choroby zakaźne na znaczne odległości [7, 10].

Wśród czynników tych wyróżnia się czynniki negatywne i pozytywne. Czynniki negatywne wpływają bezpośrednio na przyczynę wystąpienia choroby zakaźnej, odporność organizmu i stan zdrowia. Mogą doprowadzić do skrócenia długości życia w wyniku obecności w środowisku człowieka czynników toksycznych, rakotwórczych i zakaźnych, promieniowania, pyłu, hałasu, stresu psychicznego. Nie bez znaczenia jest specyfika pracy zawodowej, rodzaj wysiłku fizycznego, ilość czasu wolnego, chroniczny niedobór aktywności ruchowej.

Czynników pozytywnych, chroniących życie, zwiększających komfort życia, ogólną sprawność i przyczyniających się do wydłużenia czasu przeżywania, jest mniej. Są nimi: zdrowy styl życia, rezygnacja z używek i narkotyków, odpowiednia ilość snu, prawidłowe nawyki żywieniowe, aktywność ruchowa, higieniczny tryb życia, uwarunkowania genetycznie. Zmiana któregokolwiek z tych czynników może spowodować zmianę podatności na chorobę zakaźną $[6,11]$.

Skuteczne zapobieganie chorobom zakaźnym to konsekwentne przestrzeganie elementarnych zasad higieny oraz opracowanie metod uniemożliwiających rozwój chorób niewystępujących do tej pory w Polsce, zawlekanych z innych obszarów świata, stanowiących poważne zagrożenie zdrowotne. Zagadnienie to jest priorytetem Narodowego Programu Zdrowia na lata 2007-2015, kładącego nacisk na poprawę stanu zdrowia i jakości życia. Osiągnięciem tego celu będzie zmniejszenie ilości zatruć pokarmowych, zakażeń żołądkowo-jelitowych i zapadalności na choroby zakaźne i gruźlicę, stosowanie szczepień ochronnych, zwiększenie skuteczności zapobiegania chorobom zakaźnym i zakażeniom oraz ograniczenie możliwości szerzenia się chorób zakaźnych zawlekanych do Polski. Opracowując nowy program zdrowia, bazowano na wynikach monitoringu Narodowego Programu Zdrowia z lat 1998-2005. Systematyczna i konsekwentna realizacja dotychczasowych programów zdrowia pozwoliła na wydłużenie średniej długości życia, zmniejszenie umieralności niemowląt i zachorowalności na WZW B oraz osiągnięcie spadkowej liczby zgonów powodowanych chorobami układu krążenia.

Zauważalna w ostatnim czasie poprawa stanu środowiska jest niewystarczająca i wymaga intensyfikacji działań naprawczych pozwalających na polepszenie stanu sanitarnego wody pitnej, wód powierzchniowych, gleby, żywności, co pozwoli na uniknięcie wielu groźnych zaburzeń zdrowotnych. W 2015 r. oczekuje się poprawy jakości wód powierzchniowych, osiągnięcia bezpiecznego poziomu substancji szkodliwych i mikroorganizmów w wodzie pitnej, a także ograniczenia szkodliwych czynników biologicznych w środowisku życia i pracy $[7,12]$.

Profilaktyka i zapobieganie chorobom zakaźnym wiąże się też z systematycznym szerzeniem fachowej wiedzy dotyczącej higieny indywidualnej oraz środowiska, zachowań warunkujących zdrowie, źródeł zakażeń bakteryjnych, ograniczenia mechanizmów i dróg szerzenia się tych chorób, lekooporności oraz wzrostu odporności populacji. Przejawia się to w kontroli zakażeń, izolacji i leczeniu chorych oraz nosicieli, poddawaniu kwarantannie zwierząt, osób i mienia podejrzanego o zachorowanie, używaniu środków ochrony osobistej i sterylnego sprzętu medycznego, przeprowadzaniu dezynfekcji, utylizacji jednorazowego sprzętu medycznego oraz szczepień, celowym stosowaniu antybiotyków na podstawie antybiogramów, nadzorze i kontroli epidemiologicznej ludzi, zwierząt, ujęć wody oraz izolacji, leczeniu i przeprowadzaniu uboju sanitarnego zwierząt, przetwarzaniu żywności i wody oraz kontrolowaniu osób pracujących z żywnością. Sprzyjające zdrowiu warunki społeczno-ekonomiczne przyczynią się ponadto do kształtowania nawyków zdrowego stylu życia [13].

Wyzdrowienie z choroby zakaźnej wiąże się z wyeliminowaniem z organizmu czynnika chorobotwórczego z toksynami. Czynnik zakaźny może jednak pozostawać w ustroju człowieka przez wiele lat, umożliwiając wystąpienie ponownego zachorowania w momencie załamania odporności organizmu, jednak z drugiej strony przebycie choroby zakaźnej powoduje na ogół powstanie trwałej odporności.

Mikroorganizm chorobotwórczy docierający do odpowiedniego miejsca w organizmie gospodarza, pokonuje wiele mechanizmów obronnych. Zasadniczym mechanizmem obronnym człowieka jest układ odpornościowy, którego rolą jest zapobieganie inwazji drobnoustrojów do wnętrz organizmu (ryc. 1). W momencie zakażenia układ ten musi rozpoznać obecność obcych mikroorganizmów i spowodować ich unicestwienie lub całkowite usunięcie. Pojawia się wówczas obrona swoista indukowana po wykryciu antygenu lub patogenu, w której biorą udział limfocyty typu T i przeciwciała zwiększające fagocytozę, hamujące wiązanie się toksyn i bakterii z powierzchnią, neutralizujące toksyny lub nieswoista obrona immunologiczna z udziałem limfocytów T i limfocytów B. Pierwszy kontakt $\mathrm{z}$ antygenem skutkuje powstaniem komórek pamięci przyspieszających reakcję w przypadku ponownego z nim kontaktu. Nieswoista odpowiedź immunologiczna ma elementy składowe: układ dopełniacza, mikroflorę fizjologiczną, laktoperoksydazę, laktoferynę, lizozym, pH kwasu żołądkowego i kwasów tłuszczowych zewnętrznej warstwy skóry.

Do obrony przed drobnoustrojami chorobotwórczymi zalicza się też wydzieliny i wydaliny (łzy, ślina, śluz, mocz), a także czynności fizjologiczne (kichanie, kaszel). Ich zadaniem jest mechaniczne usuwanie bakterii patologicznych i zapobieganie przyczepianiu ich do organizmu gospodarza. Bariery mechaniczne w postaci zdrowej, o nieprzerwanej ciągłości skóry, błon śluzowych i mucyny skutecznie zapobiegają penetracji bakterii $[1,4,5]$.

\section{BAKTERYJNE ZAKAŻENIA PRZEWODU POKARMOWEGO}

Zakażenia przewodu pokarmowego stanowią poważny problem ludności świata. Podstawowym objawem chorobowym jest infekcyjna choroba biegunkowa, szczególnie niebezpieczna dla niemowląt, dzieci w wieku przedszkolnym i osób w podeszłym wieku. Przyczynia się ona do dużej liczba przypadków hospitalizacji i znacznego odsetka zgonów, przewyższającego 


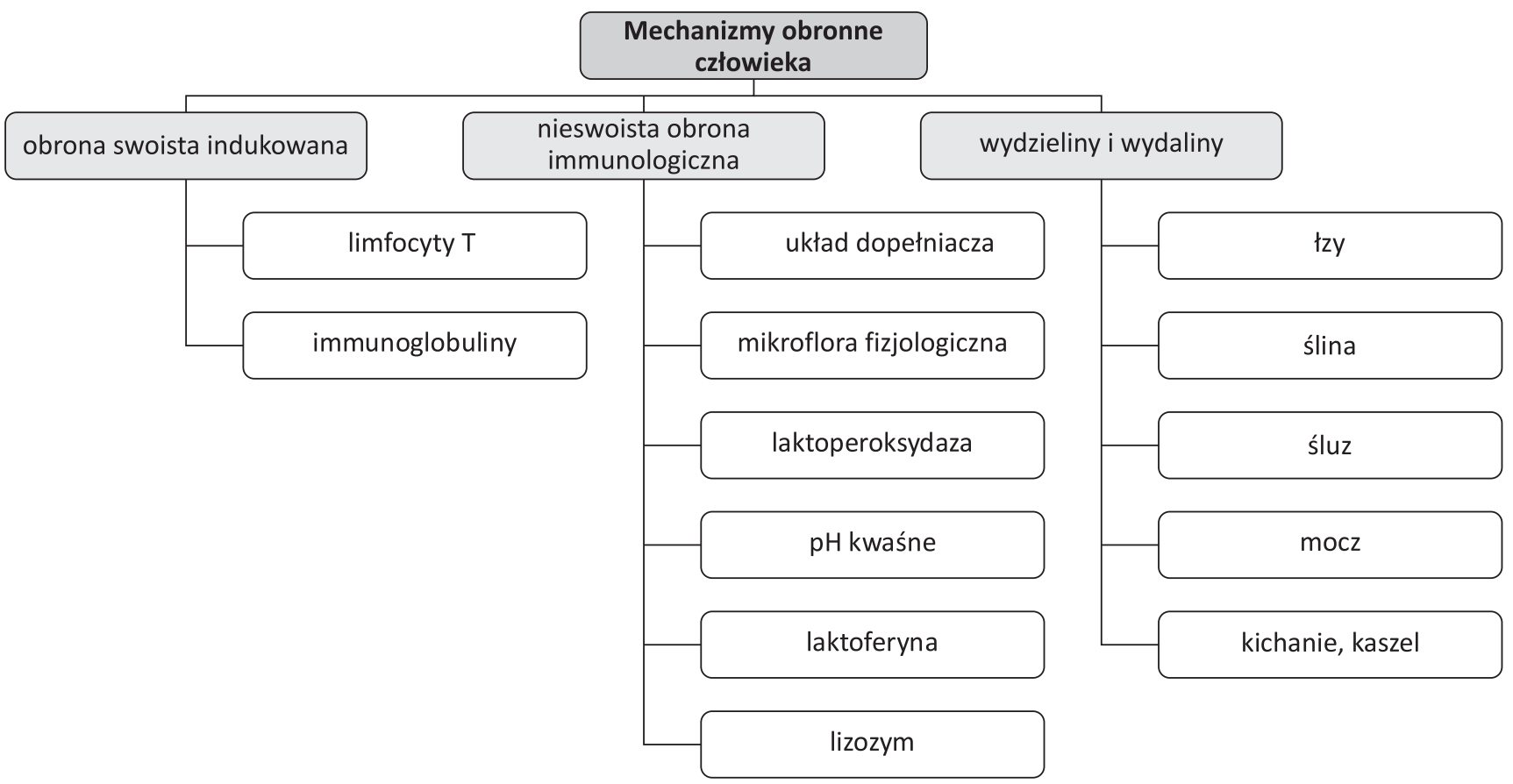

RYCINA 1. Mechanizmy obronne człowieka

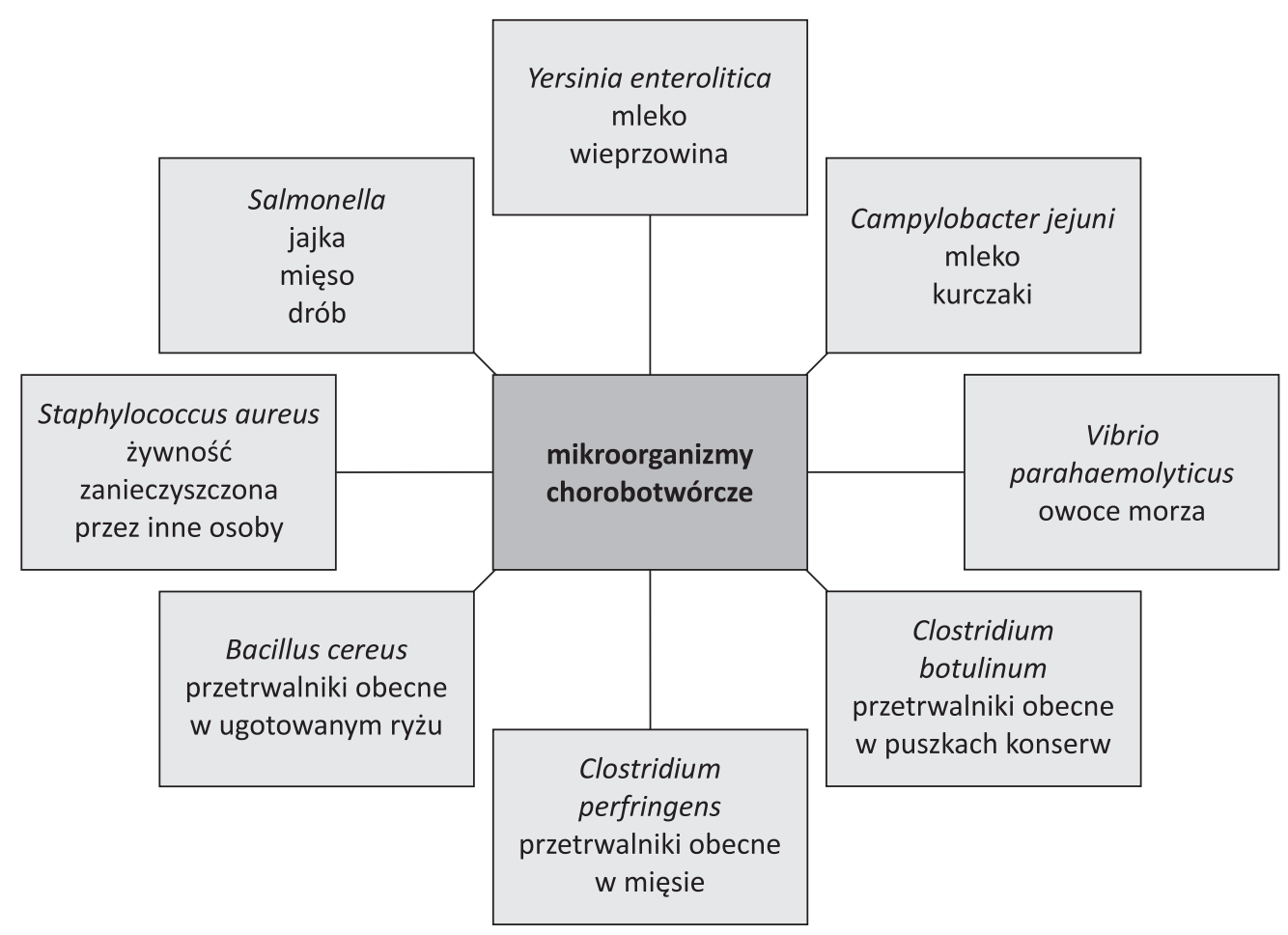

RYCINA 2. Mikroorganizmy chorobotwórcze wywołujące zatrucia pokarmowe i miejsce ich występowania

przypadki śmiertelne spowodowane chorobami układu sercowo-naczyniowego. Biegunka przebiega z gorączką, bólami brzucha, zwiększoną częstością wypróżnień o półpłynnej lub płynnej konsystencji z domieszką lub bez domieszki krwi, śluzu i ropy, czemu towarzyszą nudności i wymioty. Typ, charakter i czas trwania biegunki pozwalają na określenie kategorii zakażenia żołądkowo-jelitowego i czynników etiologicznych, niezbędnych do celów klinicznych, epidemiologicznych i leczniczych. W Polsce obowiązuje rejestracja epizodów biegunki u dzieci do 2. r.ż. Odrębne rejestry dotyczą duru brzusznego, durów rzekomych A, B, C, salmonelloz, czerwonki i zatruć pokarmowych pochodzenia bakteryjnego. 
Zakażenia przewodu pokarmowego połączone z biegunką są w krajach rozwijających się i rozwiniętych jedną z głównych przyczyn zgonów osób dorosłych. Z danych Zakładu Epidemiologii Państwowego Zakładu Higieny z 2008 r. wynika, że w Polsce odnotowano ponad 9000 zachorowań na salmonellozę i ponad 7000 zakażeń jelitowych spowodowanych zakażeniem innymi bakteriami. Pałeczki Salmonella sp. powodują w Polsce ok. 75\% przypadków ostrych nieżytów żołądkowo-jelitowych, zespołów durowych i przewlekłego nosicielstwa. Hospitalizację zaleca się przy ostrej biegunce o etiologii zakaźnej przebiegającej z odwodnieniem, ubytkiem powyżej 10\% masy ciała, uporczywymi wymiotami, perforacją jelita i wystąpieniem gorączki durowej. Wprowadzenie antybiotyków do leczenia zakażeń układu trawiennego nie jest terapią powszechnie stosowaną, jednakże użycie antybiotyków jest bezwzględną koniecznością w jelitowych zakażeniach bakteriami Shigella, Salmonella oraz Yersinia enterocolitica. Łatwa dostępność antybiotyków spowodowała powstawanie szczepów drobnoustrojów niewrażliwych na wdrażane leki. Ważną grupę stanowią drobnoustroje alarmowe, tzw. alertpatogeny: Staphylococcus aureus, Streptococcus pyogenes, Enterococcus spp., Enterobacteriaceae, Pseudomonas aeruginosa, Acinetobacter spp., Neisseria meningitidis, Streptococcus pneumaniae oraz Mycobacterium spp.

Jelitowe zakażenia przewodu pokarmowego rozprzestrzeniają się drogą pokarmową po spożyciu zakażonej wody lub żywności zawierających toksyny bakteryjne, a do transmisji czynnika chorobotwórczego przyczyniają się muchy i brudne ręce. Patogeneza zakażenia zależna jest od właściwości biologicznych drobnoustroju oraz mechanizmów obronnych gospodarza. Właściwości genetyczne bakterii warunkują łatwość przenoszenia się i rozprzestrzeniania, wytwarzania toksyn, uszkadzania komórek i tkanek, umiejętność utrzymywania się przy życiu w środowisku enzymów proteolitycznych, śluzu, kwasów i żółci $[3,14,15]$.

Mikroorganizmy chorobotwórcze wywołujące zatrucia pokarmowe i miejsce ich występowania przedstawiono na rycinie 2.

Nieodzownym warunkiem uniknięcia bakteryjnych zakażeń przewodu pokarmowego jest zachowanie podstawowych zasad higieny osobistej, przestrzeganie terminów przydatności do spożycia produktów żywnościowych, jak i przestrzeganie zaleceń sanitarnych stosowanych przy produkcji, przechowywaniu i dystrybucji produktów spożywczych [14]. Konieczność zgłoszenia w rejonowej stacji sanitarno-epidemiologicznej każdego przypadku biegunki o etiologii bakteryjnej nakłada ustawa o chorobach zakaźnych i zakażeniach [16].

\section{SEPSA - JEJ POWIKŁANIA I ROKOWANIA}

Sepsa jest zespołem klinicznym będącym uogólnioną odpowiedzią zapalną na zakażenie organizmu drobnoustrojami, głównie bakteriami Gram-ujemnymi, dodatnimi lub florą mieszaną. Infekcja rozpoczyna się po pokonaniu przez mikroorganizm chorobotwórczy barier ochronnych gospodarza. Obecność drobnoustrojów we krwi jest wynikiem wniknięcia ich do naczynia krwionośnego i rozprzestrzenienia się toksycznych produktów bakteryjnych w krążeniu. Zakażenie krwi potwierdzają badania laboratoryjne - izolacja drobnoustrojów chorobotwórczych drogą posiewów bakteriologicznych wykonywanych z krwi lub płynu mózgowo-rdzeniowego. W przebiegu sepsy dochodzi do wysiewu z krwią drobnoustrojów z ogniska zapalnego do tkanek i narządów. Objawia się to gorączką lub hipotermią, hipotensją, tachykardią, dreszczami, przyspieszonym oddechem, hipoksemią tętniczą, leukopenią lub leukocytozą, zaburzeniami świadomości, dysfunkcją nerek, wątroby, trombocytopenią i/lub zespołem rozsianego wykrzepiania wewnątrznaczyniowego (disseminated intravascular coagulation - DIC). Rozwojowi posocznicy spowodowanej bakteriami Gram-ujemnymi sprzyjają współistniejące choroby: cukrzyca, choroby rozrostowe, marskość wątroby, rozległe oparzenia i stosowanie leków toksycznych dla szpiku kostnego. Sepsie wywołanej bakteriami Gram-dodatnimi sprzyjają oparzenia, wstrzyknięcie dożylne, cewnikowanie naczyń krwionośnych niejałowym sprzętem, obecność implantów i protez mechanicznych.

Sepsa może mieć pochodzenie pierwotne lub wtórne. Pochodzenie wtórne to powikłanie zakażenia dróg moczowych, zapalenia płuc u chorych intubowanych lub z tracheotomią, zakażenia ran operacyjnych i skóry. Najłatwiejszym do zlokalizowania źródłem posocznicy jest ognisko ropne w skórze, tkance łącznej, głębszych tkankach, szpiku kostnym, zatokach obocznych lub kościach. Na sepsę najbardziej narażone są osoby starsze z niewydolnością nerek, alkoholicy i chorzy przyjmujący leki immunosupresyjne. Sepsa powoduje bardzo częste powikłania, na które częściej podatni są mężczyźni niż kobiety. Doprowadzają one do rozwoju zespołu ostrej niewydolności oddechowej, zaburzeń wydolności układu krążenia, hipotonii opornej na leczenie, zaburzeń krzepliwości, uszkodzeń wątroby. Z tego względu, że sepsa atakuje cały organizm, rokowania z nią związane są zawsze poważne i uzależnione od takich czynników jak: wiek chorego, stan układu odpornościowego i współistniejące choroby. Pomimo ciągłego postępu diagnostycznego i terapeutycznego, częstość odnotowywanych przypadków sepsy wzrasta rocznie o 1,5\%, a wysoka śmiertelność jest porównywana do śmiertelności spowodowanej ostrą niewydolnością serca. Sepsa przyczynia się też do wzrostu średniego kosztu hospitalizacji.

W 2001 r. powołano Polską Grupę Roboczą do spraw Sepsy pod przewodnictwem prof. Andrzeja Küblera, która zamierza wprowadzić w życie Narodowy Program Leczenia Ciężkiej Sepsy skupiający się na zapewnieniu właściwych warunków leczenia sepsy i doprowadzeniu do obniżenia śmiertelności w Polsce. Z analizy polskiej internetowej rejestracji przypadków ciężkiej sepsy wynika, że najczęstszą jej przyczyną są bakterie Gram-ujemne (48\% odnotowanych przypadków) i Gram-dodatnie (43\% odnotowanych przypadków). Wśród bakterii Gram-ujemnych ciężką sepsę wywołują szczepy Escherichia coli, Klebsiella pneumoniae, Enterobacter, Pseudomonas aeruginosa, ponadto gronkowce - Staphylococcus aureus, Staphylococcus epidermidis i Enterococcus [4, 17]. 


\section{MECHANIZM POWSTANIA I TYPY ZAKAŻEŃ SZPITALNYCH}

Zakażeniem szpitalnym jest każde zakażenie, do nabycia którego dochodzi w czasie hospitalizacji pacjenta, a rozpoznanie kliniczne potwierdzone jest analizami laboratoryjnymi wykonanymi jeszcze w trakcie pobytu chorego w szpitalu lub po jego opuszczeniu. Za zakażenie to uznaje się przypadki wystąpienia objawów po 48 godz. od chwili przyjęcia na leczenie szpitalne lub 48 godz. od wykonania procedury inwazyjnej, a także po wypisaniu chorego ze szpitala w okresie dłuższym, jeśli doszło do zakażenia prątkami gruźlicy, wirusem ospy wietrznej, grzybami, WZW A, B, C (wirusowe zapalenie wątroby typu A, B, C) lub ludzkim wirusem niedoboru odporności (human immunodeficiency virus - HIV). Może ono dotyczyć chorego i pracownika medycznego wykonującego obowiązki służbowe. Częstość występowania zakażeń szpitalnych zależy od sposobu organizacji opieki zdrowotnej, specyfiki szpitala i oddziałów szpitalnych, umiejętności zachowania elementarnych zasad higieny osobistej oraz poziomu ekonomicznego kraju oraz zamieszkiwanej strefy klimatycznej.

Zakażenia szpitalne są istotnym współcześnie problemem medycznym we wszystkich krajach świata bezpośrednio związanym z pobytem w szpitalu i wykonywanymi w tym czasie czynnościami diagnostyczno-terapeutycznymi. Pomimo wysiłku personelu szpitala utrzymującego higienę na najwyższym poziomie, cel ten nie zawsze zostaje osiągnięty. Dlatego też szpital staje się miejscem, w którym dochodzi do nabywania i rozprzestrzeniania się oporności drobnoustrojów. Antybiotykooporność bakterii wymaga tworzenia specjalnych zespołów nadzoru mikrobiologiczno-epidemiologicznego zajmującego się kontrolą zakażeń szpitalnych, wprowadzaniem programów kontroli zakażeń i zużycia antybiotyków, monitorowaniem szpitalnych zakażeń ran chirurgicznych. Szczególnie niebezpiecznymi patogenami bytującymi w środowisku szpitalnym są: szczepy gronkowca złocistego metycylinoopornego (methicillin resistant Staphylococcus aureus - MRSA), enterokoki wankomycynooporne (vancomycin resistant enterococcus VRE), Gram-ujemne pałeczki wytwarzające laktamazy typu $\beta$-laktamazy o rozszerzonym zakresie działania substratowego (extended spectrum $\beta$-lactamaze - ES $\beta \mathrm{L}$ ) oraz laseczki Clostridium difficile. Do zakażeń tych dochodzi również w lecznictwie otwartym - w przychodniach lekarskich, poradniach specjalistycznych, prywatnych gabinetach lekarskich, ambulatoriach, gabinetach zabiegowych, rehabilitacyjnych i kosmetycznych, gdyż współcześnie stosowane metody diagnostyczne wiążą się z naruszeniem ciągłości tkanek, co z kolei powoduje powstanie wrót zakażenia.

Biorąc pod uwagę pochodzenie źródła infekcji, wyróżnia się trzy typy zakażeń: endogenne, egzogenne i niesklasy fikowane.

Zakażenia endogenne spowodowane są wykonywaniem zabiegów leczniczych w ognisku zakażenia zajmowanym przez florę własną pacjenta, zakażeniem miejsca operowanego własną florą bakteryjną pacjenta przeniesioną ze skóry lub błon śluzowych oraz nieprzestrzeganiem podstawowych zasad higieny. Zakażeniem takim jest zapalenie płuc związane naruszenie ciągłości tkanek (nakłuta skóra, naczynie krwionośne lub mięsień) umożliwiające wnikanie patogenów do organizmu

$\downarrow$

odczyn zapalny lokalny lub uogólniony $\downarrow$

czasowe lub trwałe upośledzenie funkcji oraz struktury tkanek i narządów przy współistniejącej chorobie $\downarrow$

\begin{tabular}{|c|}
\hline pogorszenie stanu zdrowia pacjenta \\
$\downarrow$ \\
\hline konieczność zmiany dotychczasowego sposobu \\
leczenia i pielęgnacji pacjenta \\
$\downarrow$
\end{tabular}

zmiana stosowanych dotychczas środków leczniczych i badań diagnostycznych

$\downarrow$

zmiana rokowań i życia chorego

wzrost kosztów pobytu pacjenta w szpitalu w związku z przedłużeniem leczenia $\downarrow$

wzrost liczby osób czasowo lub trwale niezdolnych do pracy i zgonów w każdym przedziale wiekowym

RYCINA 3. Mechanizm powstawania zakażenia szpitalnego

z zastosowaniem oddychania wspomaganego i wentylacji mechanicznej. Zakażenia egzogenne wywołuje szpitalna flora bakteryjna przenoszona od pacjenta za pośrednictwem sprzętu medycznego, żywności lub personelu medycznego, nieprawidłowo przeprowadzanych procesów sterylizacji, dezynfekcji, utylizacji odpadów szpitalnych, niewłaściwym praniem bielizny chorych, sprzątaniem pomieszczeń szpitalnych i przygotowaniem posiłków. Przyczyną są także rozległe rany u pacjentów z obniżoną odpornością. Do zakażeń niesklasyfikowanych zalicza się infekcje okołoporodowe i zakażenia wewnątrzmaciczne $[3,7,10,16,18,19]$. Mechanizm powstawania zakażenia szpitalnego przedstawiono na rycinie 3 .

\section{ZAPOBIEGANIE ZAKAŻENIOM SZPITALNYM}

Zapobieganie zakażeniom szpitalnym jest działaniem mającym na celu przerwanie drogi przenoszenia drobnoustrojów w warunkach szpitalnych. Świadomie i konsekwentnie muszą być podejmowane wszelkie działania, takie jak: stosowanie maseczek ochronnych i rękawiczek jednorazowego użytku, sterylnej bielizny operacyjnej i sterylnych rękawiczek, sterylizacja i dezynfekcja powierzchni, ciała pacjentów i personelu asystującego podczas czynności diagnostycznych, odzieży ochronnej personelu medycznego, bielizny i pościeli chorych, specjalistycznych narzędzi diagnostycznych i operacyjnych, wprowadzenie procedur usuwania odpadów medycznych i fizjologicznych, wdrażanie nowoczesnej profilaktyki z uwzględnieniem 
wszystkich ogniw łańcucha epidemicznego. Ważne jest okresowe przeprowadzanie dezynfekcji środowiska szpitalnego, a w przypadku zakażenia sprzętu medycznego nieodzowna jest całkowita wymiana specjalistycznych narzędzi do zabiegów inwazyjnych, aparatów do mierzenia ciśnienia tętniczego krwi, stetoskopów oraz sprzętu komputerowego.

W zapobieganiu chorobom zakaźnym i zakażeniom obowiązuje poddawanie się badaniom wykrywającym choroby zakaźne, pobranie materiału do badań z rąk personelu medycznego, poddawanie się obowiązkowym szczepieniom ochronnym, leczeniu, izolacji, kwarantannie, hospitalizacji oraz nadzorowi epidemiologicznemu.

Zapobieganie zakażeniom egzogennym w szpitalu wymaga wprowadzenia procedur uniemożliwiających krzyżowanie się dróg komunikacyjnych czystych i brudnych, zapewnienia właściwej klimatyzacji, a także zwrócenia uwagi na pomieszczenia o wysokim ryzyku rozprzestrzeniania się patogenów szpitalnych. Niezwykle istotna jest higiena rąk personelu z zachowaniem prawidłowej techniki mycia rąk i użyciem środków dezynfekujących lub żeli na bazie alkoholu. Zalecane jest stosowanie jałowych rękawiczek przed i po każdym kontakcie z chorym, z materiałem biologicznym oraz sprzętem mającym z nim styczność i zabiegami wymagającymi zachowania jałowych warunków.

Kontrolowanie zakażeń szpitalnych wiąże się z koniecznością wdrożenia szpitalnej polityki antybiotykowej mającej na celu ustalenie sposobu leczenia zakażeń. Rygorystyczne przestrzeganie tej polityki znajduje odzwierciedlenie $\mathrm{w}$ postaci zmniejszenia występowania szczepów opornych, a bezzasadne stosowanie kilku antybiotyków jednocześnie o podobnym spektrum działania skutkuje selekcją szczepów opornych. Stosowanie bezpłatnych próbek antybiotyków może doprowadzić do zastosowania ich niezgodnie z receptariuszem szpitalnym i niekontrolowanego rozwoju opornych szczepów bakterii.

Istnienie szpitalnych szczepów opornych jest poważnym problemem ekonomicznym, gdyż całkowita ich eliminacja jest niemożliwa. Możliwe jest jednak ograniczenie tego problemu poprzez świadomą współpracę wszystkich pracowników szpitalnych podlegających nieustannej edukacji.

Do ograniczenia zakażeń szpitalnych może przyczynić się opracowanie sposobu identyfikacji nosicieli szczepów wieloopornych. Dokonuje się tego podczas przyjmowania pacjenta do szpitala. Wykonywane są przesiewowe badania mikrobiologiczne w celu wczesnego wykrycia bezobjawowego nosicielstwa szczepów niebezpiecznych (MRSA, VRE). Bardzo pomocna jest biologia molekularna wykorzystująca reakcję PCR (polymerase chain reaction - reakcja łańcuchowa polimerazy), której metody cechują się dużą czułością i swoistością oraz krótszym czasem przeprowadzania badania $[3,10,18,19,20]$.

\section{BIOTERRORYZM}

Broń biologiczna jest jednym z najgroźniejszych środków masowego rażenia. Międzynarodowe uregulowania prawne zakazują jej stosowania, jednakże istnieje ciągłe ryzyko jej użycia dla celów terrorystycznych oraz prowadzenia działań wojennych. Broń biologiczna ma wiele cech przemawiających za wykorzystaniem jej do aktów terrorystycznych - jest łatwo dostępna, tania w produkcji, można ją szybko wytworzyć w istniejących i funkcjonujących laboratoriach, jest ponadto skuteczna, niewidoczna w czasie ataku, łatwa do ukrycia, przenoszenia i transportu, a niezwykle trudna do szybkiego wykrycia i identyfikacji, gdyż jest bezwonna. Przy zachowaniu niezbędnych procedur jest w pełni bezpieczna dla producenta. Najbardziej niebezpieczna jest ta broń biologiczna, której czynniki zostały zmodyfikowane genetycznie, ponieważ jej identyfikacja i leczenie skutków jej użycia mogą okazać się trudne do osiągnięcia, a wręcz niemożliwe.

Pierwsze objawy użycia broni biologicznej uwidaczniają się po kilku dniach w postaci masowych zachorowań. Do ataku terrorystycznego z użyciem broni biologicznej może dojść w wyniku rozpylenia aerozolu, skażenia żywności i ujęć wody. Droga aerozolowa jest najbardziej skutecznym sposobem ataku bioterrorystycznego. Użycie aerozolu w pomieszczeniach zamkniętych może wywołać efekt obezwładniający, a nawet śmiertelny. Obiektami ataków terrorystycznych mogą być dworce kolejowe, stacje metra, porty lotnicze, duże centra handlowe, obiekty sportowe i budynki rządowe. Znaczne straty w ludności powoduje użycie czynnika skutkującego znaczną śmiertelnością (dżuma, wąglik, gorączka krwotoczna, ospa prawdziwa). Efekt psychologiczny i znaczne straty ekonomiczne przynosi użycie patogenu powodującego znaczną zachorowalność, ale niewielką śmiertelność (bruceloza, tularemia, gorączka Q). 0 przeprowadzonym ataku bioterrorystycznym świadczy duża liczba chorych z podobnymi objawami, znaczna liczba chorób o niewyjaśnionej etiologii, pojawienie się w populacji nietypowych chorób lub występowanie ich w nietypowej dla nich porze roku. Czynnikami ataku bioterrorystycznego mogą być bakterie i toksyny bakteryjne (tab. 2) [10, 21].

TABELA 2. Potencjalne czynniki ataku bioterrorystycznego

Czynniki ataku bioterrorystycznego

bakterie i wywoływane przez nie schorzenia

bakterie i ich toksyny bakteryjne

\author{
Bacillus anthracis - wąglik \\ Yersinia pestis - dżuma \\ Brucella mellitensis - gorączka maltańska \\ Brucella suis - posocznica \\ Burkholderia maleli - nosacizna \\ Francisella tularensis - tularemia \\ E. coli-enterokrwotoczne zapalenie jelit
}

Clostridium botulinum - botulina

Clostridium perfringens - toksyna epsilon

Shigella dysenteriae - shigatoksyna

Staphylococcus aureus - enterotoksyna B 
Podstawowym wyznacznikiem chorobotwórczości bakterii są wytwarzane przez nie toksyny, będące białkami, peptydami lub lipopolisacharydami, które doprowadzają do uszkodzenia komórek, choroby, a nawet śmierci zainfekowanego organizmu. Efekty biologiczne działania toksyn bakteryjnych mogą być wielokierunkowe i zróżnicowane, zależnie od dawki, ale nawet nanogramowe ilości endotoksyny spotykane w wyjałowionych roztworach do wlewów dożylnych mogą wywołać efekt pirogenny. Stąd konieczność poddawania płynów infuzyjnych badanym na obecność endotoksyny [3].

Wyróżnia się toksyny bakteryjne wydzielane na zewnątrz komórki bakteryjnej (egzotoksyny) oraz uwalniane po rozpadzie komórki bakteryjnej (endotoksyny). Do egzotoksyn należą: toksyna botulinowa (jad kiełbasiany), błonicza, tężcowa i erytrogenna oraz toksyny wytwarzane przez gronkowce. Szczególnie niebezpieczne są enterotoksyny oddziałujące na przewód pokarmowy człowieka i powodujące ostre zatrucia pokarmowe [22].

Egzotoksyny to będące produktem metabolizmu żywych i nieuszkodzonych bakterii wysoce toksyczne substancje białkowe rozpuszczalne w wodzie, których nawet mikrogramowe dawki wydzielane do tkanki lub narządu mogą powodować śmierć. Są silnymi antygenami. Występują przeważnie u bakterii Gram-dodatnich. Ulegają zniszczeniu pod wpływem kwasów, enzymów trawiennych i temperatury $60^{\circ} \mathrm{C}$. Wpływ formaldehydu i temperatury $37^{\circ} \mathrm{C}$ powoduje utratę ich zjadliwość w ciągu 6 tyg., ale bez utraty właściwości antygenowych, dzięki czemu mogą być stosowane jako szczepionki w profilaktyce chorób zakaźnych. Nie działają po podaniu drogą pokarmową. Egzotoksyny mogą powodować m.in. martwicę skóry, porażenie nerwowo-mięśniowe i zatrucie pokarmowe. Do bakterii wytwarzających egzotoksyny należą: Corynebacterium diphtheriae, Clostridium tetani, Streptococcus pyogenes, Staphylococcus aureus, Shigella shigae, Pasteurella pestis. Egzotoksyna została odkryta po raz pierwszy przez Émile Roux, potem przez Aleksandra Yersina, Emila von Behringa i Shibasaburo Kitasato [11, 22, 23].

Pod koniec XIX w. Klein wykazał, że drobnoustroje niewytwarzające egzotoksyn mogą działać toksycznie na ustrój dzięki znajdującym się wewnątrz komórki bakteryjnej endotoksynom. Endotoksyny są kompleksami lipopolisacharydowymi wytwarzanymi przez bakterie Gram-ujemne po rozpadzie komórki. Są słabymi jadami bakteryjnymi, nie przechodzą w anatoksynę, działają po podaniu doustnym. Dają bardzo szybko objawy chorobowe: wstrząs endotoksyczny, obniżenie ciśnienia tętniczego krwi, agregację płytek krwi, leukocytozę, reakcje skórne, podwyższoną ciepłotę ciała, indukcję nieswoistej odporności na zakażenie. W odróżnieniu od egzotoksyn są słabo toksyczne. Wysoka ciepłooporność powoduje, że zawierające je produkty żywnościowe nie nadają się do spożycia nawet po długotrwałym gotowaniu. Są białkami i mają właściwości pełnych antygenów [3, 22].

\section{PODSUMOWANIE}

Organizmy jednokomórkowe, jakimi są bakterie obecne w wodzie, glebie, powietrzu oraz żywności spożywanej przez ludzi i zwierzęta, a także toksyny bakteryjne wytwarzane przez te bakterie, są przyczyną wielu schorzeń zagrażających zdrowiu i życiu człowieka. Pomimo nieustannego rozwoju medycyny kryteria rozpoznawania tych schorzeń mogą być niespecy ficzne, ponieważ rozpoznanie i leczenie ich nastręcza poważnych trudności i wymaga znacznych nakładów.

Zakażenia bakteryjne stanowią w krajach rozwijających się i rozwiniętych jedną z głównych przyczyn zgonów osób dorosłych. Zakażenia szpitalne i powikłania, jakie powodują, są istotnym problemem medycznym i społecznym, gdyż mimo znacznego wysiłku wkładanego w jego rozwiązanie, w dalszym ciągu nastręczają wielu trudności w postaci pogorszenia stanu zdrowia pacjenta hospitalizowanego, wprowadzenia zmian dotychczasowego leczenia, przedłużenia czasu pobytu w szpitalu i związanych z tym kosztów oraz zmian dotyczących rokowania i życia chorego. Zastosowanie antybiotykoterapii nie zawsze jest działaniem powszechnie stosowanym ze względu na możliwość powstania narastającej lekooporności szczepów bakterii.

Liczne czynniki ryzyka przyczyniają się do wystąpienia klasycznych form zakażeń bakteryjnych i ich nowych postaci, jednak zarówno człowiek, jak i bakterie posiadają własne mechanizmy obronne uniemożliwiające zapoczątkowanie zakażenia. Sprzyja temu także bezwzględne przestrzeganie elementarnych zasad higieny i opracowanie metod zapobiegających rozwojowi chorób, zwłaszcza niewystępujących dotąd w naszym kraju, a także szerzenie fachowej wiedzy, prowadzące do uzyskania zachowań warunkujących zdrowie. Opracowywane programy zdrowia i szczepienia ochronne są pomocne w profilaktyce, zapobieganiu chorobom zakaźnym i przeciwdziałaniu szerzenia się zakażeń bakteryjnych. Widoczna poprawa stanu zdrowia to wymierna konsekwencja wdrażania działań naprawczych pozwalających na wydłużenie długości życia, zmniejszenie zachorowalności i umieralności, a skuteczność działania to gwarancja uniknięcia w przyszłości wielu groźnych zaburzeń zdrowotnych.

\section{PIŚMIENNICTWO}

1. Zagrożenia wynikające z zakażeń bakteryjnych. http://www.publikacje. hdwao.pl/zagrozenia_bakteryjne.php (6.08.2012).

2. Alexander Fleming. http://pl.wikipedia.org/wiki/Alexander_Fleming (6.08.2012).

3. Zaremba M.L., Borowski J.: Mikrobiologia lekarska. PZWL, Warszawa 1997, 125-733.

4. Choroby zakaźne i pasożytnicze. Ed.Z. Dziubek. PZWL, Warszawa 1996, 35-77.

5. Jędrychowski W.: Epidemiologia w medycynie klinicznej i zdrowiu publicznym. Wyd. Uniw. Jagiell., Kraków 2010, 13-20.

6. Miller M., Zieliński A.: Zdrowie publiczne - misja i nauka. Przegl Epidemiol. 2002, 56, 547-557.

7. Narodowy Program Zdrowia na lata 2007-2015. Załącznik do Uchwały nr 90/2007 Rady Ministrów z dn. 15.05.2007 r.; 23-74.

8. Korzeniewska-Koseła M.: Tuberculosis in Poland in 2011. Przegl Epidemiol. 2013, 67, 277-281. 
9. OstrekJ., Baumann-Popczyk A., Sadkowska-Todys M.: Zatrucia i zakażenia pokarmowe w Polsce w 2011 r. Przegl Epidemiol. 2013, 67, 563-565.

10. Bzdęga J., Gębska-Kuczerowska A.: Epidemiologia w zdrowiu publicznym. PZWL, Warszawa 2010, 206-354.

11. Sygit M.: Zdrowie publiczne. Wolters Kluwer Polska, Warszawa 2010, 542-608.

12. Litwiejko A.: Podstawy zdrowia publicznego w aspekcie prawno-społecznym, Wrocławskie Wyd. Oświatowe, Wrocław 2010, 55-66.

13. Choroby zakaźne. http://pl.wikipedia.org/wiki/Choroby_zakaźne (6.08.2012).

14. Garlicki A.M., Leśniak M.R.: Leczenie chorób biegunkowych o etiologii zakaźnej u dorosłych. Przegl Epidemiol. 2009, 63, 395-400.

15. Rozporządzenie Ministra Zdrowia z dn. 11.03.2005 r. w sprawie rejestrów zakażeń zakładowych oraz raportów występowaniu tych zakażeń. Dz.U. z 2005 r., nr 54, poz. 484.
16. Ustawa z dn. 5.12.2008 r. o zapobieganiu oraz zwalczaniu zakażeń i chorób zakaźnych u ludzi. Dz.U. z 2008 r., nr 234, poz. 1570.

17. Paradowski M., Szablewski M., Majda J.: Zaburzenia biochemiczne w przebiegu sepsy. Bad Diagn. 2006, 12 (8/9), 53-58.

18. Mirecka A.: Zakażenia szpitalne. Bad Diagn. 2007, 13 (8/9), 53-58.

19. Ustawa z dn. 6.09.2001 r. o chorobach zakaźnych i zakażeniach. Dz.U. z 2001 r., nr 126, poz. 1384.

20. Bulanda M., Tyski S., Ciuruś M.: Zakażenia szpitalne w Polsce - stan wiedzy na IV. 2011 r. Raport programu „Stop zakażeniom szpitalnym. Program promocji higieny szpitalnej".

21. Chomiczewski K.: Zagrożenie bioterroryzmem. Przegl Epidemiol. 2003, 57 (2), 349-359.

22. Toksyny. http://medycyna.linia.pl/toksyny.html (6.08.2012).

23. Egzotoksyna bakteryjna. http://swiatbiologii.com/Egzotoksyna-bakteryjna.html (6.08.2012). 